\title{
Automotive Brand in Sultanate of Oman: Customers Perspective
}

\author{
Amitha $\mathrm{KN}^{1}$, Anan Akthar ${ }^{2}$, Brindha $\mathrm{N}^{3}$, Kakul Agha ${ }^{2}$ and Nagesh Poojary ${ }^{2}$, \\ ${ }^{1}$ Senior Executive HR, Wipro technologies, India \\ ${ }^{2}$ Middle East College, Muscat, Sultanate of Oman \\ ${ }^{3}$ Karpagam College of Engineering, Coimbatore, India
}

Correspondence should be addressed to: Nagesh Poojary; nagesh.bk@gmail.com

Received date: 14 June 2012 ; Accepted date:17 June 2013.; Published date: 15 August 2013

Academic Editor: Shastri L Nimmagadda

Copyright (C 2013. Amitha KN, Anan Akthar, Brindha N, Kakul Agha and Nagesh Poojary. Distributed under Creative Commons CC-BY 3.0

\begin{abstract}
The customer experience contributes significantly in shaping automotive brand name and it plays a wider role in capturing competitive market share. This article is an attempt to analyze the concept of automotive branding and apply the concept to selected company in the Sultanate of Oman. The concept of automotive branding is drawn upon existing theories, models, and practices across fields of marketing, human resource management and organizational behavior. The recent literature on corporate branding emphasizes the importance of brand values: a brand is seen to encapsulate the additional values that are inherent or associated with the corporation and its products and services. Various literatures from marketing, organizational behavior and human resource management were analyzed to build the conceptual framework for an automotive company Renault to illustrate adoption of automotive branding in the Sultanate of Oman. The analysis shows that customers of Renault are sensitive to the brand and customers closely watch branding initiatives. It also makes clear that the attitude and behavior of customers is a significant determinant of brand value.
\end{abstract}

Keywords: Brand management, Automotive brand, Marketing strategy

Cite this Article as: Amitha KN, Anan Akthar, Brindha N, Kakul Agha and Nagesh Poojary (2013), "Automotive Brand in Sultanate of Oman: Customers Perspective," Journal of Supply Chain and Customer Relationship Management, Vol. 2013 (2013), Article ID 535786, DOI: 10.5171/2013.535786. 


\section{Introduction}

The evolving and ever expanding automotive business is one of the many changes happening in Sultanate of Oman's business landscape.Automotive branding is about capturing essence of an automotive organization from the perspective of customers. Specifically, it articulates an organization's value proposition in terms of customer relation, quality of product/service and culture.The value of automotive brand is immense and it is a strategic tool to attract customers. Most importantly, an investment on building brand play a vital role in maintaining customer loyalty. The increased focus on customer satisfaction and customer loyalty is leading many firms to rethink their brand strategy.In the past, German companies in particular have created strong automobile brands that consumers rank among the most prestigious brands of all. Consequently, brand management from the perspective of customer opinion is one of the major factors of success in the automotive industry. In the Sultanate of Oman, brand is critical for gaining competitive advantage on others. This is particularly true for automotive sector to become recognized icons in the society.Automotive industry has been considered as a challenging areaat present as it has great contribution in economic growth and in some countries it is the major source of national economic growth.

This research makes an attempt to analyze and conceptualize automotive brand in Sultanate of Oman from the perspective of customer base. The research focusses on the automotive industry in Oman specifically the Renault brand. The content of this study consists of brief introduction about automotive industry in Oman, followed by the influence of Economy. Also, the product brand is discussed because it concerns with the automotive brands common and/or known to omanis and expatriates residing and working in the Sultanate of Oman. Current research work focusses on Renault brand and its products in the context of customer braning.

Renault has been named the fastest growing automotive brand in the Gulf region at the end of the first quarter of 2011, according to the latest report by the Middle East Automobile Council (MEAC). The positioning complements the car and commercial vehicle manufacturer's 214 pc sales growth in the first quarter of 2011, compared with the same period in 2010. This growth led Renault to be the third highest selling European automotive brand in the Gulf region, after BMW and Mercedes, and the leading non-luxury European car maker in the region. As a result, Renault entered the league table of Top 20 Brands in the Gulf region ranking 19th, up nine places compared to the same period last year. Renault has also confirmed its status as the number one European brand in Oman, a position it occupied at the end of 2010 . Simultaneously, Renault has achieved 58 pc growth in the UAE and 378 pc growth in Qatar, making it the third European brand in Qatar. In 2010, Renault sold more than 4,277 vehicles in the GCC countries, an 87 PC increase compared to 2009. By the end of 2011, Currently Renault has 24 showrooms in the GCC and Iraq. The increase in the number of Renault branches and parts centers in Oman has helped to better serve and satisfy customers. Renault is the leading European brand in the first quarter of 2011. Renault has also confirmed its status as the number one European brand in Oman, a position it occupied at the end of 2010 . Simultaneously, Renault has achieved 58\% growth in the UAE and $378 \%$ growth in Qatar, making it the third European brand in Qatar.

Hence, statistical analysis clearly indicates that Renault is one of the important automotive brands in Oman. Therefore, Renault is an interesting case study for study customer branding. A thorough investigation on Renault brand through several types of 
data gathering such as interview and survey questionnaires are presented. In addition, a customer satisfaction survey is also conducted to determine the satisfactory level of consumers in using Renault car as well as with the services provided by service provider.

\section{Literature Review}

Identity is currently in the forefront of corporate marketing literature (Balmer, 2008).Corporate brand can't be viewed in complete isolation because identity based view of the corporation promotes a corporate brand identity as one of many identity types. While corporate identity includes a combination of personal, organizational and behavioral traits ( $\mathrm{He}$ and Avinandan, 2009; Balmer,2008; Melewar, 2003), corporate brand identity corresponds to an identity type that encompasses specific features and values that are chosen and associated with a corporate br and to represent the company and its offer to the market (Balmer and Greyser, 2002).

Corporate brand identity is commonly materialized through, but not limited to the corporate name, market offer, logotypes, slogans, employee behavior, and different forms of planned communications (Aaker, 2004; Balmer, 2001a; 2005; Balmer and Gray, 2003).Through these sources of information, the corporate brand identity is translated by the market, resulting in a corporate brand image and reputation while combining associations and expectations into an informal contract between the company and its various stakeholders(Balmer and Greyser, 2002). Corporate brand identity provides the link between a company and its stakeholders (Aaker, 2004; Barnett, 2012), informing audiences about what to expect from the company.

If the idea of brands being about customers is true, it also makes clear that the attitude and behavior of customers will be a significant determinant of brand value. Interestingly, there exists an intriguing phenomenon among Chinese American consumers. Most Chinese Americans prefer Japanese or European brands of automobiles over US brands. Indeed, one would find only a few US brands of automobiles (e.g. Fords, Chevrolets, or Chryslers) in the parking lot at shopping centers, churches, and restaurants that Chinese Americans patronize regularly in the USA. Rather, one would most likely see either Japanese-brand automobiles (e.g. Hondas, Toyotas, and Nissans) or European-brand automobiles (e.g. VWs, BMWs, and MercedesBenzes) at those places. Research on this extreme pattern indicated that one of the factors is negative stereotyping of US brands of automobiles by general US consumers (Ross, 2008). Further research revealed that ethnicity, country-of-origin or country image, and interpersonal influence might serve as drivers of automobile purchase and consumption phenomenon (Jawahitha, Nada and Haneen, 2011). Therefore, the consumer end of the brand equation is vital in building automotive brand. The societal structure in the Sultanate of Oman is highly networked. The individual customer perception of brand image and his perspective may influence other potential customers. Due to these reasons, it is important to persuade consumers to believe in products of an institution and connect the customers with a brand. Consequently, customers who feel good about the synergy between the business model and brand values tend to stay loyal and more engaged leading to increased productivity.

Automobile can be considered as a need especially if someone is residing and working in a country which is dominated by desert and mountain ranges like Sultanate of Oman. Having an automobile is very essential in everyday life as it is very advantageous for every residents of Oman to have at least one type of automobile when public transport system is sparse. In Oman, it is important for all levels of society (including expatriates)to own an automobile, mainly for convenience and also for emergency purposes. It is necessary for any consumers to evaluate the kind of automobile that they need to 
purchase. Even though the consumer has not experienced all automotive brands, the brand experiences of other customers and general brand opinion of the public/professionals will be of interest during decision making (Olins, 2011; Roberts, 2012). However, decision making is a complex activity which depends on multiple factors such as customer requirements, safety needs, budget, maintenance etc. The sultanate is known to be a country that loves its automobiles. With automobile savvy buyers, Oman has a market for every type of vehicles. It is not a coincidence that Oman is the place where the Middle East's first electric vehicle is set to be manufactured (Business Today, 2011). To add to that, the economy here is buoyant and resilient; both of which ensure a smooth drive for automakers. Recent survey on growth market outlook indicated that Omani GDP growth in increasing faster and future prospects are looking better (GBCM, 2011).Road infrastructure, strict traffic laws and safety requirements are the other positive aspects of the Omani market. In addition, Oman has a system where one national dealer is used by auto manufacturers as opposed to multiple dealers across the country.

Over the years, the Omani consumer has also become more aware of his choices and the quality of the product, customer service and ambience. It is estimated that from 2002 to 2007, the automobile market in the sultanate tripled in size. In Oman, new car launches have been happening on a regular basis, despite the global economic turbulence. The industry expects that the next few years may see an increase in demand for smaller cars. The sale of commercial vehicles is also expected to pick up with infrastructure projects like roads, airports, bridges, etc. being announced this year. This article is written at a meta level, giving a broad perspective, and based on research studies and on-the-ground experience in Oman. This study provides overview of automotive brand in Oman. However, it focuses on a particular brand of automobile which is Renault brand. The marketing strategies and customer satisfaction strategies in Oman are discussed and evaluated in this study.

\section{Renault's Identity in Oman}

The automobile sector is a multi-billion dollar industry across the world. In certain parts of the world, it is one of the major contributors to the country's national income itself. With the rapid increase in the number of commuters on the roads and improved infrastructural developments of the states, global automobile brands have ensured their presence in such countries. One such global brand known as the Renault, and how it has made its presence felt in the Sultanate of Oman. To achieve the above objective of interpreting customer's perception of brand, proposed research first look and critically evaluate the various product offerings of the Renault vehicle in Oman's market.

Renault has always been an automaker and a brand in tune with its times. It has built up its reputation since 1898 through innovative technology, a broad product line-up and racing wins. In Oman, Suhail Bahwan Automobiles (SBA) is the exclusive dealers for all Renault vehicles and is responsible for growth of the brand in the Sultanate. Today, Renault's authorized dealers in Oman are making certain that Renault's heritage and experience trickles down to the customer. Importantly, SBA has achieved the distinction of being the No.1 Renault dealer in sales in the GCC region. SBA increased the sales of Renault vehicles in Oman by a whopping 172 per cent over 2008 (YTD).

The Renault group is reporting record sales volumes for 2010 , with 2,6 million vehicles sold $(+14 \%$ on 2009). This performance is driven by strong growth outside Europe. The Group has increased its global market share $(3.7 \%)$ in line with targets. For 2011, the Group plans to continue expanding outside Europe and to defend its positions within Europe in a market where the end of government aids is expected to have a severe impact. 


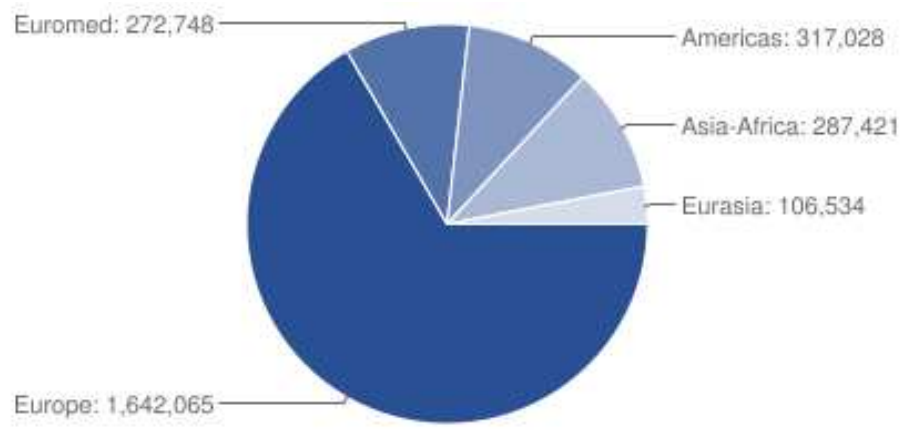

Fig. 1: Renault Group Sales in 2010 (without LADA)

The sultanate has provided the highest sales for Renault in the Middle East, while the European car maker almost doubled its sales volume in Asia-Africa in 2010 compared to 2009. There are around sixteen locations in the sultanate for the brand's after sales service, of which ten have dedicated technical teams to cater to customer needs, officials said at a recent media briefing at Renault's service centre.

Considering the intense competition in Oman's market in the lower, middle and upper-middle segment of automobile brands, the rating of Renault brand from the perspective of customers is discussed. This is done by carrying out a detailed competitive analysis of Renault in Oman. After looking at the competitive environment, the Renault's brand awareness level among the people of Oman is analyzed. Even the best brands with the best product offerings may also fail if it fails to communicate the right message to its target market. Therefore, study analyses Renault stand in communicating its message to the people of Oman. The study also provides some valuable insight on the Renault's customer satisfaction. It will analyze how well the Renault brand has been able to provide value to its customers and thus, gain a good market share.

To achieve all these purposes; a structured survey was conducted which has helped in drawing valuable results. The findings of the survey have shown how a combination of the right brand, with the right dealership and with the right product offerings can yield impressive results.

\section{Methodology}

In this study, three types of survey questionnaire and semi-structured interviews were developed and used to collect data. The content of the survey questionnaires and semi-structured interview protocol was designed by taking into consideration the level of customer's satisfaction and the performance of Renault car compared to other automotive brands in the Sultanate. Semi structured interviews was conducted by the researcher which involve a series of open ended questions based on the strategies made by Suhail Bahwan Automobiles, LLC to check the customer's satisfaction on Renault car as well as the marketing strategies. Therefore, in the semi structured interview, the Senior Sales 
Manager of Suhail Bahwan Automobiles, LLC was given series of questions and asked to respond to every question. When explaining his ideas, his understanding was investigated more deeply by means of follow-up questions.

Three types of survey questionnaire were used in this study. Firstly, a customer satisfaction survey was conducted to identify appreciation of Renault's products. The questionnaire was divided into three subsections highlighting delivery of the Car, features of Renault Car and overall Satisfaction. The second survey questionnaire consists of five questions and the respondents were also asked to select the appropriate response. The aim of this survey is to determine the brand types of customers regarding the automobiles whether Omanis or expatriates. The third survey was conducted on companies. Its aim is to determine the automotive brand owned by company.

Customer satisfaction survey was conducted on one hundred respondents to find the satisfaction levels of its Omani and expatriate consumers. After the administration of survey questionnaires, the consumer's responses were evaluated and analyzed. In the analysis process, items of the instruments were evaluated for both positive and negative responses. The frequencies and percentages of choices that were given by the consumers were calculated for each of the survey questionnaire items. And then, consumer's response and the percentages of consumers whose response is Renault car for each of the survey question items were defined and presented in next section. After the interviews, it was analyzed to know more strategies used in marketing or selling the Renault car.

\section{Results and Analysis}

As discussed in previous sections, one hundred samples were used in the survey. Figure 2 shows the age distribution of samples. Larger portion of respondents (57\%) of the sample comes from age group between 20-29 years old, followed by $42 \%$ from the age group 30-39 years old and 1\% from the age group 40-49 years old.

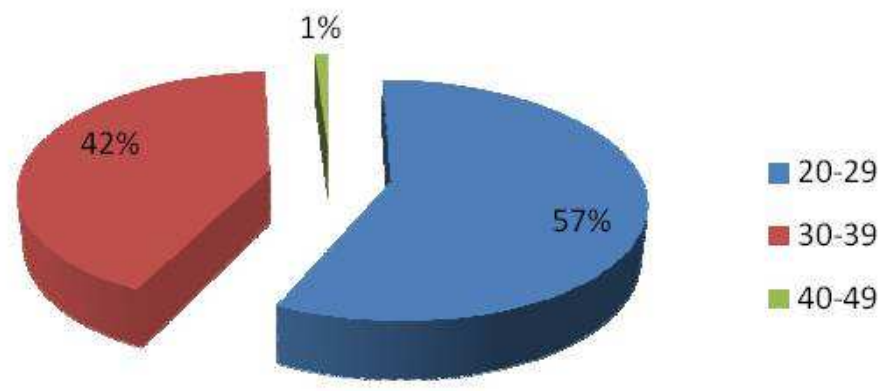

Fig. 2: Age distribution of samples.

Majority (57\%) of the samples belong to 2029 age groups. Second bigger age group is $30-29$ with $42 \%$ respondents. Only $1 \%$ respondents were from 40-49 age groups.
In total, $66 \%$ of the respondents were male and $34 \%$ were female. Figure 3 shows the occupation wise distribution of gender. The larger respondents were professionals from both male and female genders.With regard to the occupation; most of the respondents are 
professionals with a percentage of $54 \%$, followed by the businessman with $34 \%$ and $12 \%$ were students. In addition, most of the respondents are Omanis with a percentage of $79 \%$ and expatriates were only $21 \%$.

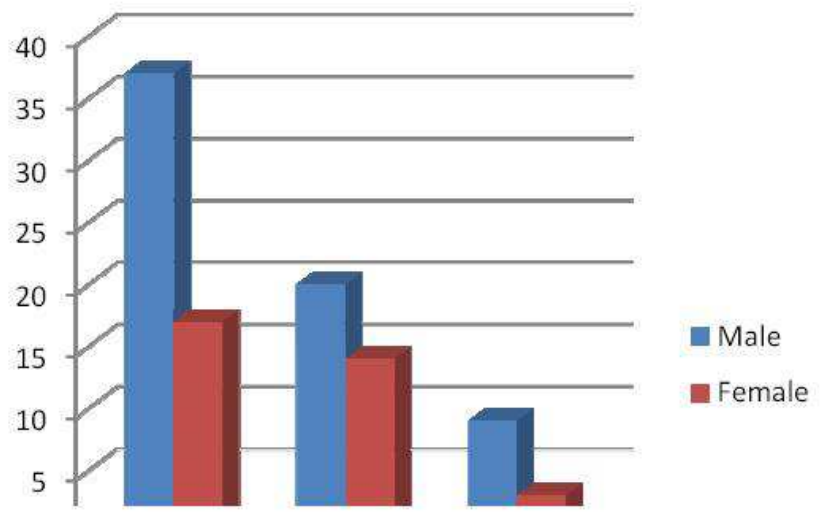

Fig. 3: Sample Distribution According to Gender and Occupation.

The customers of Renaults were asked ten questions regarding Renault's customer service. Majority of customers (95.2\%) gave a positive response in receiving Renault car on time of delivery; all the freebies were given as well as the information that a customer need to know regarding the Renault car was explained. And only $4.8 \%$ has negative response. Customers were asked ten questions on interiors of car, luxury and comfort levels. Survey indicated that $99.8 \%$ received Renault car with complete accessories and parts and only $0.2 \%$ has wind noise and steering and handling issues. It can be interpreted that it is a factory defects. Overall satisfaction survey on Renault experience indicated that $89.8 \%$ were highly satisfied with the Renault, 9.2\% were satisfied and only $1 \%$ somewhat satisfied. Hence, the feedback can be interpreted as customers are happy with Renault products and Renault is dedicated to serve its valued customer.

A study was also conducted to find out based on the overall experience, how likely customers would purchase another Renault car, if they need to replace an existing car. Interestingly, $89 \%$ of the consumers are very likely to purchase another Renault car, 10\% are likely to purchase and $1 \%$ is somewhat likely to purchase another Renault car. Furthermore, a question was asked to find out whether existing customers would like to recommend Renault car to their friends, relatives and family. Survey indicated that $90 \%$ of the respondents were very likely to recommend the Renault car to their friends, family and relatives.

The results of the survey can be interpreted as customers of Renault car have a very high satisfactory level with the product. It also indicates that Renault is perceived as good brand among its customers in terms of customer experience. As discussed in previous sections, being a new player in the Automotive Industry in the Sultanate, Renault has made its name in terms of service quality, product features and the safety features of the car itself. The customer experience confirms Renault's achievements in the context of service and product 
satisfaction. Renault brand has a very high impact in Oman market as per the customer feedback. It can compete with any other automotive brand, because Renault car is a European car which is affordable compared to any other European cars due to its strong relationship with its customer base. It also offers a wide range of product lines such as Sedan, Coupe, 4WD etc. The product sare built according to a world class taste of range of customers. This indicates that larger respondent satisfactions as different category of customers are served by the range of products. Most importantly, the notion of automotive brand in Sultanate of Oman in the context of its customers is reaffirmed. Customer satisfaction is crucial in building a brand.

\section{Conclusion}

The objectives of this study were to analyze automotive brand and examine empirically automotive brand status with an example. Study was conducted on customers of Renault brand and customer perceptions, expectations were captured. The findings showed customers loyalty to the brand based on their experiences with the brand. Results indicate the close association between brand image and customer expectations, indicating the need for automotive sectors to strategize the customer relationship. Since branding involves customer loyalty, it is imperative that companies evaluate the position of their automotive brand periodically using various metrics to make meaningful marketing of their brand.

\section{References}

Aaker, D.A. (2004), "Leveraging the corporate brand", California Management Review, Vol. 46 No. 3, pp. 6-18.

Balmer, J.M.T. (2001a), “Corporate identity, corporate branding and corporate marketing. Seeing

through the fog", European Journal of Marketing, Vol. 35 Nos 3/4, pp. 248-91.
Balmer, J.M.T. (2005), “Corporate brands: what's new?",Commicacao e Sociedade, Vol. 8, pp. 163-78.

Balmer, J.M.T. (2008), "Identity based views of the corporation: insights from corporate identity, organisational identity, social identity, visual identity, corporate brand identity and corporate image", European Journal of Marketing, Vol. 42 No. 9, pp. 879906.

Balmer, J.M.T. and Gray, E.R. (2003), "Commentary - corporate brands: what are they? What of them?", European Journal of Marketing, Vol. 37 Nos 7/8, pp. 972-97.

Balmer, J.M.T. and Greyser, S.A. (2002), "Managing the multiple identities of the corporation", California Management Review, Vol. 44 No. 3, pp. 72-86.

Barnett, Michael (2012), "Branded experiences are the big attraction", Marketing Week (01419285). 4/26/2012, Vol. 35 Issue 16, p27-27. 1p.

Business Today (2010), "Taking the High Road", Business Today, Issue July $2010 \mathrm{He}$, H.W. and Avinandan, M. (2009), "Corporate identity and consumer marketing: a process model and research agenda", Journal of Marketing Communications, Vol. 15 No. 1, pp. 1-17.

GBCM Research (2011), “Oman Economic Outlook", Gulf Baader Capital Markets S.A.O.C. http://ae.zawya.com/researchreports/gis/2 0110120_gis_092634.pdf

Jawahitha, Nada and Haneen (2011), "Employer Branding in Selected Companies in United Arab Emirates", Communications of the IBIMA, Volume 2011 (2011), Article ID 228533, DOI: $10.5171 / 2011.228533$

Melewar, T.C. (2003), "Determinants of the corporate identity construct: a review of the literature", Journal of Marketing Communications, Vol. 9 No. 4, pp. 195-221. 
Olins, wally (2011), "A brand's real value is nothing, except in the eye of the beholder", Marketing Week (01419285). 8/25/2011, Vol. 34 Issue 34, p10-10.1p.

Ross, Elspeth (2008), "The power behind the brand", Brand Strategy, Mar 2008, Issue 220, p34-35. 2p.
Roberts, Jo (2012), "Young brands sparkle as the strong grow stronger", Marketing Week (01419285). 5/24/2012, Vol. 35 Issue 20, p17-17.1p.

Vallaster, C. and de Chernatony, L. (2006), "Internal brand building and structuration: the role of leadership", European Journal of Marketing, Vol. 40 Nos 7/8, pp. 761-84. 